\title{
Contractuele verrekening bij faillissement: de Hoge Raad gooit de remmen los
}

\author{
Prof. mr. W.A.K. Rank*
}

\begin{abstract}
1 Inleiding
Verrekening is een bijzondere wijze van tenietgaan van verbintenissen. $\mathrm{Zij}$ vertoont facetten van nakoming, maar heeft tevens zekerheidsaspecten. Verrekening is in het BW geregeld in afdeling 6.1.12. De bepalingen inzake verrekeningsbevoegdheid in het BW zijn van regelend recht. Partijen kunnen overeenkomen dat bepaalde wettelijke vereisten niet zullen gelden, kunnen nadere vereisten stellen, of verrekening geheel uitsluiten. Grenzen aan deze vrijheid stellen art. 6:236 sub f, 6:237 sub g en 7:632 lid $4 \mathrm{BW}$ en, in het geval van faillissement, surseance van betaling en schuldsaneringsregeling (art. 53, 54, 234, 235, 307 en 313 jo. art. 54 Fw). Recentelijk heeft de Hoge Raad een arrest gewezen waarin deze grenzen voor het geval van faillissement (en daarmee ook voor het geval van surseance en schuldsaneringsregeling) verder worden opgerekt dan tot voor kort door veel in de praktijk werkzame juristen voor mogelijk werd gehouden op grond van de tekst van de wet, de paritas creditorum en een eerdere uitspraak van de Hoge Raad zelf. Het arrest in kwestie betreft HR 15 november 2019, ECLI:NL:HR:2019:1789 (Crienen/Bontrup). In dit arrest overweegt de Hoge Raad dat het wederkerigheidsvereiste van art. $53 \mathrm{FW}$, net als dat van art. 6:127 BW, niet van dwingend recht is. Volgens de Hoge Raad staat art. $53 \mathrm{Fw}$ er dan ook niet aan in de weg dat de wederpartij van de gefailleerde jegens de curator een beroep doet op een voor de datum van de faillietverklaring met de gefailleerde overeengekomen beding op grond waarvan zij bevoegd is haar schuld aan de gefailleerde te verrekenen met een vordering van een andere partij op een ander dan de gefailleerde.
\end{abstract}

In dit artikel wordt het zojuist genoemde arrest van de Hoge Raad besproken. Aan de orde komt wat de Hoge Raad nu precies heeft beslist en wat daarnaast uit het arrest kan worden afgeleid, wat de consequenties van de uitspraak zijn voor de financiële praktijk en of het een juiste beslissing betreft. Bij het laatste gaat het mij niet zozeer om de altijd enigszins subjectieve vraag of de uitspraak voldoende recht doet aan de belangen van alle spelers (banken, curatoren, overheden), maar veeleer om de vraag of zij deugt uit oogpunt van rechtssystematiek.

\footnotetext{
Prof. mr. W.A.K. Rank is hoogleraar Financieel Recht te Leiden en Of Counsel bij NautaDutilh te Amsterdam.
}

Het gaat daarbij om de vraag of de uitspraak past in het systeem van de wet en aansluit bij de in de wet geregelde gevallen. Dat is niet alleen relevant voor de wetenschap, maar ook voor de praktijk, met het oog op de rechtszekerheid en de voorspelbaarheid van rechterlijke uitspraken. ${ }^{1} \mathrm{Om}$ het arrest in de juiste context te kunnen plaatsen, wordt eerst de regeling van de verrekeningsbevoegdheid besproken. In dat verband passeren zowel de regels van het BW als die van de Fw de revue. Het artikel wordt afgesloten met een conclusie. ${ }^{2}$

\section{Wettelijke verrekening buiten insolventie} Op grond van art. 6:127 lid $2 \mathrm{BW}$ is een schuldenaar bevoegd tot verrekening wanneer hij een prestatie te vorderen heeft die beantwoordt aan zijn schuld jegens dezelfde wederpartij en hij bevoegd is zowel tot betaling van de schuld als tot het afdwingen van de betaling van de vordering. In deze bepaling ligt een viertal cumulatieve vereisten besloten: (a) wederkerig schuldenaarschap, (b) gelijksoortigheid van prestatie, (c) bevoegdheid tot betaling en (d) afdwingbaarheid van nakoming. Ik licht deze vereisten hierna kort toe.

\section{a) Wederkerig schuldenaarschap}

Partijen moeten wederkerig elkaars schuldeiser en schuldenaar zijn. Aan dit vereiste is niet voldaan indien een partij crediteur en debiteur is in verschillende hoedanigheid. Dit is evenmin het geval indien aan een zijde vordering en schuld in gescheiden vermogens vallen (art. 6:127 lid 3 BW). Een hoofdelijk schuldenaar kan zijn schuld niet verrekenen met een tegenvordering van een medeschuldenaar op de schuldeiser. De pandhouder of vruchtgebruiker van een vordering is, ook indien hij tot inning bevoegd is, geen schuldeiser in de zin van het artikel. Hetzelfde geldt voor degene die is gevolmachtigd tot inning. Met een tegenvordering van de schuldenaar op de

1. Zie over het belang van de rechtssystematiek en de taak van de rechtswetenschapper bij het inpassen van nieuwe wetgeving en rechtspraak in het bestaande systeem recentelijk R.M. Wibier, De taak van de rechtswetenschapper, NJB 2020, p. 883-887.

2. Dit artikel vormt een bewerking van een gelijknamige presentatie van de auteur op het NautaDutilh R\&I Ontbijtseminar van 17 december 2019. Het arrest is ook besproken door N.E.D. Faber, JOR 2020, afl. 1, p. 242-251, R.M. Wibier, AA 2020, afl. 3, p. 269-273 en Y.A.Y. Sevinck $\&$ A.C. Rozeman, Meerpartijenverrekening in faillissement - HR 15 november 2019, Bb 2020/7, p. 145-146. 
pandhouder, vruchtgebruiker of gevolmachtigde kan derhalve niet worden verrekend. Degene die derdenbeslag heeft gelegd en jegens wie de derde tot betaling is veroordeeld, is wat de verrekening betreft wel als schuldeiser van de derde-beslagene te beschouwen. ${ }^{3}$

Belangrijke wettelijke uitzonderingen op het wederkerigheidsvereiste vinden we in art. 6:130 BW, art. 3:265d Wft en art. 24 Invorderingswet 1990 (IW 1990). Art. 6:130 BW laat soms verrekening toe, hoewel partijen door overgang van een vordering niet (langer) elkaars schuldenaar en schuldeiser zijn. Art. 3:265d Wft voorziet in bepaalde gevallen in verrekening van rechtswege van een bankspaardeposito eigen woning en de eigenwoningschuld bij een hypothecaire geldlening, ook als de bank waarbij het bankspaardeposito wordt aangehouden niet de crediteur van de eigenwoningschuld is. Op grond van art. 24 IW 1990 is de Ontvanger bevoegd bepaalde door hem aan de belastingplichtige uit te betalen bedragen te verrekenen met bepaalde van een andere tot dezelfde fiscale eenheid behorende maatschappij te innen bedragen, ongeacht of die andere maatschappij in surseance van betaling of in staat van faillissement verkeert.

Zonder een wettelijke of contractuele basis behoort verrekening van een schuld aan een bepaalde partij met een vordering op een andere partij niet tot de mogelijkheden, omdat dit afbreuk zou doen aan het voor verrekening essentiële vereiste van wederkerigheid. Dit is in 1999 door de Hoge Raad bevestigd in een geval waarin de Ontvanger, zonder te beschikken over de thans uit hoofde van art. 24 IW 1990 aan hem toekomende wettelijke bevoegdheid, zich beriep op verrekening op grond van art. $53 \mathrm{Fw}$ van schulden aan en vorderingen op verschillende tot een fiscale eenheid behorende partijen. ${ }^{4}$

\section{b) Gelijksoortigheid van prestatie}

De schuldenaar moet bevoegd zijn de schuld met het aan hem verschuldigde te betalen. Het criterium geldt voor de prestatie als geheel, bijkomstige bedingen daaronder begrepen. Het voorwerp van de verbintenissen behoeft niet kwantitatief gelijk te zijn. Zo is de schuldenaar van een generieke verbintenis tot verrekening bevoegd met een hem specifiek toekomende prestatie van dezelfde soort. Het omgekeerde is niet mogelijk. ${ }^{5}$ Ter zake van verbintenissen tot betaling van verschillende valuta is verrekening in beginsel alleen mogelijk indien de schuldenaar niet tot betaling effectief verplicht is en derhalve de bevoegdheid heeft om in de aan hem verschuldigde valuta te voldoen.

\section{c) Bevoegdheid tot betaling}

De schuldenaar moet bevoegd zijn om zijn eigen verbintenis na te komen. Daartoe is niet noodzakelijk dat de schuld opeis-

\footnotetext{
3. TM, Parl. Gesch. (N)BW Boek 6, p. 491.

4. HR 15 januari 1999, ECLI:NL:HR:1999:ZC2820, NJ 2000/49 (Wilderink q.q./Ontvanger).

5. TM, Parl. Gesch. (N)BW Boek 6, p. 491.
}

baar is. Verrekening is echter uitgesloten indien aan de schuld een termijn ten behoeve van de crediteur is verbonden. ${ }^{6}$

\section{d) Afdwingbaarheid van nakoming}

De schuldenaar moet bevoegd zijn om betaling van zijn vordering af te dwingen. Die bevoegdheid ontbreekt indien de vordering niet opeisbaar is (art. 6:38-40 BW), indien zij voorwaardelijk is (art. 6:21 BW), indien de wederpartij een opschortingsrecht heeft (art. 6:52 e.v. BW) of indien het om een natuurlijke verbintenis gaat (art. 6:3 BW). ${ }^{7}$ Beletselen als bedoeld in art. 6:33 BW (beslag, beperkt recht, bewind) staan aan verrekening in de weg omdat de rechthebbende de betaling van zijn vordering niet kan afdwingen. ${ }^{8}$ Verhindering van nakoming door overmacht staat niet in de weg aan verrekening (art. 6:79 BW). Verjaring van de rechtsvordering van de verrekenende partij sluit verrekening niet uit. Datzelfde geldt voor bij wijze van gunst verleend uitstel van betaling of executie (art. 6:131 BW).

\section{Wettelijke verrekening bij insolventie}

\subsection{Algemeen}

De regeling van afdeling 6.1.12 BW geldt niet, althans niet over de gehele linie, indien een van de partijen in staat van faillissement of in surseance van betaling verkeert, noch indien ten aanzien van een van hen de schuldsaneringsregeling van toepassing is verklaard. Voor verrekening jegens de gefailleerde respectievelijk de boedel respectievelijk de persoon ten aanzien van wie de schuldsaneringsregeling is uitgesproken, gelden met name enkele bijzondere regels met betrekking tot de vereisten waaraan een schuld en een vordering moeten voldoen om voor verrekening in aanmerking te komen. Deze bijzondere regels vormen deels een aanvulling op en deels ook een afwijking van de in dit verband voor verrekening in het algemeen geldende regels, waaronder in het bijzonder de regels van art. 6:127 BW inzake verrekeningsbevoegdheid. Voor zover aanvullende of afwijkende regels ontbreken, zijn de algemene regels van afdeling 6.1.12 BW van toepassing.

\subsection{Wettelijke verrekening bijfaillissement}

In het geval van faillissement geldt voor verrekening jegens de gefailleerde het bijzondere verrekeningsregime van art. 53 en $54 \mathrm{Fw}$. Op grond van art. $53 \mathrm{Fw}$ kan hij die zowel schuldenaar als schuldeiser van de gefailleerde is zijn schuld met zijn vordering verrekenen, indien beide zijn ontstaan vóór de faillietverklaring of voortvloeien uit handelingen vóór de faillietverklaring met de gefailleerde verricht. Art. $53 \mathrm{Fw}$ heeft in de loop der jaren tot veel jurisprudentie geleid, met name inzake verrekening door een giro-instelling bij een betaling aan en door de gefailleerde kort voor of na de faillietverklaring. Deze jurisprudentie betreft in het bijzonder de vraag wanneer sprake is van voortvloeien uit handelingen vóór de faillietver-
6. TM, Parl. Gesch. (N)BW Boek 6, p. 491

7. MvA II, Parl. Gesch. (N)BW Boek 6, p. 494.

8. TM, Parl. Gesch. (N)BW Boek 6, p. 501. 
klaring met de gefailleerde verricht. ${ }^{9}$ Art. 54 lid 1 Fw bepaalt dat verrekening van een vóór de faillietverklaring overgenomen schuld aan of vordering op de gefailleerde niet is toegestaan indien degene die de schuld of de vordering heeft overgenomen bij de overneming niet te goeder trouw heeft gehandeld. Art. 54 lid $2 \mathrm{Fw}$ voegt daaraan toe dat na de faillietverklaring overgenomen vorderingen of schulden in het geheel niet kunnen worden verrekend. Ook art. $54 \mathrm{Fw}$ heeft tot de nodige jurisprudentie aanleiding gegeven, eveneens inzake verrekening door een giro-instelling bij betaling aan en door de gefailleerde rondom de faillietverklaring. ${ }^{10}$

\subsection{Wettelijke verrekening bij surseance}

In het geval van surseance geldt voor verrekening jegens de boedel het bijzondere verrekeningsregime van art. 234 en 235 Fw. Dit regime is nagenoeg identiek aan het bij faillissement geldende verrekeningsregime. Op grond van art. $234 \mathrm{Fw}$ kan hij die zowel schuldenaar als schuldeiser van de boedel is zijn schuld met zijn vordering verrekenen, indien beide zijn ontstaan vóór de aanvang van de surseance of voortvloeien uit een handeling vóór de aanvang van de surseance verricht met degene ten aanzien van wie de surseance is uitgesproken. Ter voorkoming van misbruik bepaalt art. $235 \mathrm{lid} 1 \mathrm{Fw}$ dat degene die vóór de aanvang van de surseance een schuld aan of een vordering op de boedel heeft overgenomen niet bevoegd is tot verrekening indien hij bij de overneming niet te goeder trouw heeft gehandeld. Vorderingen of schulden die na de aanvang van de surseance zijn overgenomen, kunnen op grond van art. 235 lid $2 \mathrm{Fw}$ sowieso niet worden verrekend.

\subsection{Wettelijke verrekening bij schuldsanering}

In het geval van een schuldsaneringsregeling geldt een strikter verrekeningsregime dan bij faillissement of surseance. Op grond van art. 307 lid $1 \mathrm{Fw}$ kan hij die zowel schuldenaar als schuldeiser is van de persoon ten aanzien van wie de schuldsaneringsregeling is uitgesproken zijn schuld slechts verrekenen met zijn vordering indien beide zijn ontstaan vóór het uitspreken van de schuldsaneringsregeling. Art. $313 \mathrm{Fw}$ verklaart art. $54 \mathrm{Fw}$ op de hier bedoelde verrekening van overeenkomstige toepassing.

\subsection{Wettelijke verrekening bij belastingvorderingen}

De regeling van afdeling 6.1.12 $\mathrm{BW}$ geldt evenmin voor de verrekening van belastingvorderingen door de Ontvanger. Voor deze verrekening geldt het bijzondere verrekeningsregime van art. 24 IW 1990. Volgens deze regeling is de Ontvanger ten aanzien van de belastingplichtige bevoegd (en op diens verzoek verplicht) aan de belastingplichtige uit te betalen bedragen en van deze te innen bedragen ter zake van de in het artikel genoemde belastingen en heffingen met elkaar te verrekenen. Art. 53, 54, 234, 235 en 307 Fw zijn op de hier bedoelde verrekening van overeenkomstige toepassing. Art. 24 IW

9. Zie o.m. de rechtspraak genoemd door Rank, in: T\&C BW 2019 en in: T\&C Vermogensrecht 2019, art. 6:114 BW, aant. 6 onder c en d.

10. Zie wederom de rechtspraak genoemd door Rank, in: T\&C BW 2019 en in: T\&C Vermogensrecht 2019, art. 6:114 BW, aant. 6 onder $\mathrm{c}$ en d.
1990 bevat een uitzondering op het in art. 6:127 BW neergelegde en in art. 53, 234 en $307 \mathrm{Fw}$ herhaalde wederkerigheidsvereiste als het gaat om door de Ontvanger uit te betalen en te innen bedragen waarvan de verschuldigdheid materieel is ontstaan over dan wel in een tijdvak waarin de belastingplichtige deel uitmaakt of uitmaakte van een fiscale eenheid. Volgens de bepaling kunnen aan de belastingplichtige uit te betalen bedragen behalve met van deze te innen bedragen ook worden verrekend met te innen bedragen van een andere maatschappij die in dat tijdvak deel uitmaakt of uitmaakte van de fiscale eenheid, ongeacht of de belastingplichtige of die andere maatschappij in surseance van betaling of in staat van faillissement verkeert. Art. 24 IW 1990 behelst geen uitzondering op de in art. $53 \mathrm{Fw}$ neergelegde eis dat vordering en schuld beide moeten zijn ontstaan vóór de faillietverklaring of moeten voortvloeien uit handelingen vóór de faillietverklaring met de gefailleerde verricht. De Ontvanger kan in het geval van een fiscale eenheid dan ook niet aan art. 24 IW 1990 de bevoegdheid ontlenen om een teruggave omzetbelasting die na faillissement is opgekomen te verrekenen met van voor het faillissement daterende belastingschulden. Verrekening door de Ontvanger van een teruggave van omzetbelasting wegens na faillissement gebleken oninbaarheid van facturen die reeds vóór het faillissement aan derden zijn uitgereikt met een vóór de faillietverklaring ontstane belastingvordering op de gefailleerde dan wel een maatschappij waarmee deze een fiscale eenheid vormde, behoort wel tot de mogelijkheden. ${ }^{11}$ Als sprake is van een fiscale eenheid en een vordering van de moedervennootschap op de Ontvanger door de Ontvanger wordt verrekend met een schuld van een dochtervennootschap, kan de moedervennootschap - wanneer de schuld van de dochtervennootschap later in een fiscale procedure wordt verminderd het te veel verrekende in civilibus van de Ontvanger vorderen. ${ }^{12}$

\section{Contractuele verrekening}

Art. 6:127 BW bevat regelend recht. Partijen kunnen de bevoegdheid tot verrekening uitbreiden, beperken of uitsluiten. Dat contractuele bedingen ter uitbreiding van de verrekeningsbevoegdheid buiten faillissement, surseance of schuldsaneringsregeling mede kunnen worden ingeroepen jegens derden, een cessionaris, een pandhouder of een beslaglegger daaronder begrepen, is al vele jaren geldend recht. ${ }^{13}$ Bij faillissement of surseance ligt dat anders. Aangenomen wordt dat een contractuele afspraak van partijen tot uitbreiding van de verrekeningsbevoegdheid alleen aan een faillissementscurator of een bewindvoerder kan worden tegengeworpen indien en voor

11. HR 13 oktober 2017, ECLI:NL:HR:2017:2627, NJ 2017/454 (Schepel \& Miedema q.q./Ontvanger).

12. HR 13 februari 2015, ECLI:NL:HR:2015:299, NJ 2015/144 (Ontvanger/Hydepark).

13. Zie in dit verband HR 20 januari 1984, ECLI:NL:HR:1984:AG4739, NJ 1984/512 (Ontvanger/Barendregt), HR 10 maart 1995, ECLI:NL:HR:1995:ZC1661, NJ 1996/299 (Holtrop/Stevens), HR 23 juni 1995, ECLI:NL:HR:1995:ZC1770, NJ 1996/566 (FMN/PàP) en HR 29 januari 1999, ECLI:NL:HR:1999:ZC2836, NJ 1999/595 (DBV/ Sedgwick). 
zover een dergelijke afspraak binnen de parameters van art. 53 en 54 respectievelijk art. 234 en $235 \mathrm{Fw}$ blijft.

\section{a) Wederkerig schuldenaarschap}

Met betrekking tot het wederkerigheidsvereiste werd wel betoogd, onder meer met een beroep op de tekst van art. 53 Fw en het dwingendrechtelijke karakter van deze bepaling, het paritasbeginsel en HR 15 januari 1999, ECLI:NL:HR: 1999:ZC2820, NJ 2000/49 (Wilderink q.q./Ontvanger) - waarin het in art. $53 \mathrm{Fw}$ neergelegde wederkerigheidsvereiste door de Hoge Raad een essentieel vereiste voor verrekening werd genoemd -, dat een verrekeningsafspraak waarbij van het wederkerigheidsvereiste wordt afgeweken deze parameters te buiten zou gaan en dus niet tegen de faillissementscurator of de bewindvoerder zou kunnen worden ingeroepen. ${ }^{14}$ Anderen gingen er juist van uit dat dergelijke verrekeningsafspraken zonder meer faillissementsbestendig waren. ${ }^{15}$ Uit HR 15 november 2019, ECLI:NL:HR:2019:1789 (Crienen/Bontrup) blijkt thans dat het wederkerigheidsvereiste van art. 53 Fw, net als dat van art. 6:127 BW, niet van dwingend recht is en dat art. $53 \mathrm{Fw}$ er dan ook niet aan in de weg staat dat de wederpartij van de gefailleerde jegens de curator een beroep doet op een voor de datum van de faillietverklaring met de gefailleerde overeengekomen beding op grond waarvan zij bevoegd is haar schuld aan de gefailleerde te verrekenen met een vordering die zij op een andere partij heeft, met een vordering van een andere partij op de gefailleerde of met een vordering van een andere partij op een ander dan de gefailleerde.

\section{b) Gelijksoortigheid van prestatie}

Aannemelijk is dat hetzelfde geldt voor verrekeningsafspraken waarbij van het gelijksoortigheidsvereiste wordt afgeweken. Buiten de situatie van faillissement en surseance is ook nooit een uitzondering gemaakt of bepleit voor de mogelijke derdenwerking van verrekeningsafspraken waarbij wordt voorzien in verrekenbaarheid van ongelijksoortige prestaties. Voor dat geval kunnen partijen gewoon afspreken - met werking tegen een cessionaris, een pandhouder of een beslaglegger - dat vorderingen en schulden die in een verschillende valuta luiden en dus ongelijksoortig zijn met elkaar kunnen worden verrekend. Een voorbeeld van een dergelijke afspraak is te vinden in art. 25 Algemene Bankvoorwaarden 2017, volgens welke bepaling de bank een schuld aan de cliënt ook mag verrekenen met een vordering op de cliënt als vordering en schuld niet in dezelfde muntsoort luiden. De vraag is of dit ook opgaat in een insolventiesituatie. Art. 53 en $234 \mathrm{Fw}$ noemen niet het vereiste dat de te vorderen prestatie moet beantwoorden aan de schuld.

14. Zie de literatuur genoemd door A-G Valk in voetnoot 16 van zijn conclusie voor HR 15 november 2019, ECLI:NL:HR:2019:1789 (Crienen/ Bontrup), ECLI:NL:PHR:2019:783, alsmede W.A.K. Rank \& L.J. Silverentand, Chapter The Netherlands, in: W. Johnston, Th. Werlen \& F. Linck (red.), Set-off Law and Practice. An International Handbook, Oxford: Oxford University Press 2018, p. 328-329.

15. Zie de literatuur genoemd door A-G Valk in voetnoot 14 van zijn conclusie voor HR 15 november 2019, ECLI:NL:HR:2019:1789 (Crienen/ Bontrup), ECLI:NL:PHR:2019:783.
Heersende leer is echter dat dit vereiste ook geldt bij verrekening jegens de gefailleerde c.q. de boedel in het geval van faillissement of surseance, omdat verrekening nu eenmaal veronderstelt dat vordering en schuld met elkaar corresponderende prestaties betreffen. Gelet op de analogie tussen het gelijksoortigheidsvereiste en het wederkerigheidsvereiste ligt het in de rede om na HR 15 november 2019, ECLI:NL:HR:2019:1789 (Crienen/Bontrup) aan te nemen dat ook het gelijksoortigheidsvereiste in faillissement of surseance niet van dwingend recht is en dat verrekeningsafspraken waarbij van het gelijksoortigheidsvereiste wordt afgeweken aan de faillissementscurator of de bewindvoerder kunnen worden tegengeworpen. ${ }^{16}$

\section{c) Bevoegdheid tot en afdwingbaarheid van betaling}

Ook van de vereisten dat de debiteur bevoegd moet zijn tot betaling van zijn schuld en tot het afdwingen van betaling van zijn vordering kan contractueel worden afgeweken. Dat zien we bijvoorbeeld in art. 25 Algemene Bankvoorwaarden 2017, volgens welke bepaling de bank een schuld aan de cliënt in beginsel ook mag verrekenen met een vordering op de cliënt als de schuld aan de cliënt niet opeisbaar is of als de vordering van de bank op de cliënt niet opeisbaar of voorwaardelijk is. Deze vereisten worden niet gesteld in art. 53 en 234 Fw. Deze artikelen stellen uitsluitend de eis dat vordering en schuld beide moeten zijn ontstaan vóór de aanvang van de surseance of de faillietverklaring of moeten voortvloeien uit handelingen vóór de aanvang van de surseance of de faillietverklaring verricht met degene ten aanzien van wie de surseance of de faillietverklaring is uitgesproken. Een contractuele afspraak inhoudende dat een debiteur ook mag verrekenen als zijn schuld en/of zijn vordering niet-opeisbaar of voorwaardelijk zijn, kan derhalve aan de faillissementscurator of de bewindvoerder worden tegengeworpen. Volgens HR 15 november 2019, ECLI:NL:HR:2019:1789 (Crienen/Bontrup) kan echter niet in faillissement worden afgeweken van de regel dat alleen verrekening mogelijk is indien schuld en vordering vóór de faillietverklaring zijn ontstaan of voortvloeien uit handelingen vóór de faillietverklaring met de gefailleerde verricht, omdat die regel voortvloeit uit het fixatiebeginsel.

\section{Argumenten voor en tegen werking contractuele- uitbreiding verrekening in insolventie}

\subsection{Argumenten voor}

Ter adstructie van de opvatting dat een verrekeningsafspraak waarbij van het wederkerigheidsvereiste wordt afgeweken ook aan een faillissementscurator of een bewindvoerder moet kunnen worden tegengeworpen, wordt meestal verwezen naar de omstandigheid dat een faillissement in essentie gewoon een beslag is, een beslag ten behoeve van de gezamenlijke schuldeisers. De redenering is dan dat waar een dergelijke verreke-

16. Vgl. Rank \& Silverentand 2018, p. 328-329, die onder het voor HR 15 november 2019, ECLI:NL:HR:2019:1789 (Crienen/Bontrup) geldende regime twijfelden over de tegenwerpbaarheid aan een faillissementscurator of een bewindvoerder van een verrekeningsafspraak waarbij wordt afgeweken van het gelijksoortigheidsvereiste. 
ningsafspraak buiten de situatie van faillissement of surseance tegen een individuele beslaglegger kan worden ingeroepen, een dergelijke verrekeningsafspraak in faillissement of surseance ook zou moeten kunnen worden tegengeworpen aan de faillissementscurator of de bewindvoerder als representant van het collectief van de schuldeisers. Ter onderbouwing van deze opvatting wordt ook wel een beroep gedaan op de zekerheidsfunctie van de verrekening. De gedachte is dan dat een schuldeiser ook bij faillissement of surseance van zijn wederpartij op de gemaakte verrekeningsafspraak zou moeten kunnen vertrouwen. Steun voor deze opvatting en haar onderbouwing is te vinden bij diverse auteurs. ${ }^{17}$ Verder zijn er verschillende rechterlijke uitspraken waarin deze lijn wordt gevolgd. ${ }^{18}$ In zijn conclusie voor HR 15 november 2019, ECLI:NL:HR: 2019:1789 (Crienen/Bontrup) toont A-G Valk zich een enthousiast pleitbezorger van deze opvatting en de onderliggende argumenten. ${ }^{19}$ Dat hij in zijn conclusie wordt gevolgd door de Hoge Raad verbaast mij in dat licht niet echt, al verbaast het mij wel om te zien hoe gemakkelijk de A-G de Hoge Raad meekrijgt in zijn betoog. Ik kom daarop terug in paragraaf 6.

\subsection{Argumenten tegen}

Ter onderbouwing van de tegengestelde opvatting, dat wil zeggen de opvatting dat een verrekeningsafspraak waarbij van het wederkerigheidsvereiste wordt afgeweken niet aan een faillissementscurator of een bewindvoerder kan worden tegengeworpen, wordt meestal allereerst een beroep gedaan op de letterlijke tekst van art. $53 \mathrm{Fw}$ en het dwingendrechtelijke karakter van deze bepaling. Art. 53 Fw begint met de woorden 'Hij die zowel schuldenaar als schuldeiser van de gefailleerde is' en herhaalt daarmee expliciet het in art. 6:127 lid 2 BW vervatte wederkerigheidsvereiste. Gelet op de belangen die de Faillissementswet beoogt te beschermen - de belangen van álle schuldeisers -, ligt het voor de hand, zo is de redenering, om aan te nemen dat het hier om dwingend recht gaat. In het verlengde hiervan wordt in dit verband dan ook gewezen op het primaat van de paritas creditorum in een insolventiesituatie. Het honoreren van verrekeningsafspraken waarbij van het wederkerigheidsvereiste wordt afgeweken, betekent onvermijdelijk bevoordeling van een bepaalde crediteur en benadeling van andere crediteuren en doet daarmee afbreuk aan het paritasbeginsel. Verrekening is in zoverre een vorm van activabeklemming. Ten slotte wordt wel een beroep gedaan op het arrest van de Hoge Raad van 15 januari 1999, ECLI:NL:HR: 1999:ZC2820 (Wilderink q.q./Ontvanger), waarin de Hoge Raad wederkerig schuldenaarschap een essentieel vereiste voor verrekening heeft genoemd. Ook deze opvatting en haar

17. Zie de literatuur genoemd door A-G Valk in voetnoot 14 van zijn conclusie voor HR 15 november 2019, ECLI:NL:HR:2019:1789 (Crienen/ Bontrup), ECLI:NL:PHR:2019:783.

18. Zie de rechtspraak genoemd door A-G Valk in voetnoot 15 van zijn conclusie voor HR 15 november 2019, ECLI:NL:HR:2019:1789 (Crienen/ Bontrup), ECLI:NL:PHR:2019:783.

19. A-G Valk, conclusie voor HR 15 november 2019, ECLI:NL:HR: 2019:1789 (Crienen/Bontrup), ECLI:NL:PHR:2019:783. onderbouwing vinden steun bij verschillende schrijvers en zijn gevolgd in diverse rechterlijke uitspraken. ${ }^{20}$

\subsection{Waardering van argumenten pro en contra}

Natuurlijk is de eerste opvatting - bepleit door de A-G in zijn conclusie en gevolgd door de Hoge Raad in zijn arrest - aantrekkelijk voor partijen die zich bedienen van verrekeningsafspraken waarbij van het wederkerigheidsvereiste en/of het gelijksoortigheidsvereiste wordt afgeweken. A-G Valk schijnt te denken dat 'de kleine man' zal profiteren van de tegenwerpbaarheid van dit soort bedingen aan een faillissementscurator of een bewindvoerder. ${ }^{21} \mathrm{Ik}$ denk dat hij zich daarin vergist en dat het vooral grote, goed geïnformeerde schuldeisers en met name banken zijn die van dit soort bedingen gebruik maken en die dus ook de vruchten zullen plukken van de door hem bepleite en door de Hoge Raad toegestane verruiming van de verrekeningsmogelijkheden in insolventiesituaties. Daar is wat mij betreft niets op tegen, maar het is wel van belang om dit te onderkennen.

Ik realiseer mij ook dat de financieringspraktijk zich pleegt te bedienen van allerlei constructies om te bewerkstelligen dat in faillissement aan het wederkerigheidsvereiste is voldaan - zoals het bedingen van hoofdelijkheid aan de zijde van de schuldenaren en/of de schuldeisers en het doen stellen van garanties of borgtochten -, en dat het door de A-G bepleite en door de Hoge Raad bevestigde resultaat van multilaterale verrekening in faillissement op die manier toch al kon worden bereikt. In beide gevallen gaat het erom dat partijen hun contractuele relatie op een bepaalde manier vormgeven om tot multilaterale verrekening te komen. Dat zou een argument zijn om te betogen dat een multilaterale verrekeningsafspraak gewoon een praktische oplossing behelst voor een probleem dat anders op een omslachtiger wijze moet worden opgelost, met uiteindelijk dezelfde uitkomst. Ik begrijp die redenering, maar als er dan toch contractuele afspraken moeten worden gemaakt, geef ik vanuit een rechtssystematisch oogpunt de voorkeur aan een afspraak op grond waarvan tegenover de schuld aan de boedel een vordering op een derde komt te staan. Een dergelijke afspraak past in het systeem van de wet en sluit aan bij de in de wet geregelde gevallen.

Waar ik ook wat moeite mee heb, is de eclectische manier waarop de A-G omspringt met het dwingendrechtelijke karakter van art. $53 \mathrm{Fw}$. De regel dat alleen verrekening mogelijk is indien schuld en vordering vóór de faillietverklaring zijn ontstaan of voortvloeien uit handelingen die vóór de faillietverklaring met de gefailleerde zijn verricht, is zijns inziens wel van dwingend recht, maar de regel dat de verrekening moet geschieden door degene die zowel schuldenaar als schuldeiser

20. Zie de literatuur en rechtspraak genoemd door A-G Valk in voetnoot 16 van zijn conclusie voor HR 15 november 2019, ECLI:NL:HR: 2019:1789 (Crienen/Bontrup), ECLI:NL:PHR:2019:783, alsmede Rank \& Silverentand 2018, p. 328-329.

21. A-G Valk, conclusie voor HR 15 november 2019, ECLI:NL:HR: 2019:1789 (Crienen/Bontrup), ECLI:NL:PHR:2019:783, onder 3.8. 
van de gefailleerde is, is dat weer niet en kan men naar zijn oordeel 'eenvoudig opvatten als een aanduiding van wat geldt ingeval partijen geen afspraken in andere zin hebben gemakkt'.22

Ten slotte vind ik ook het terzijde schuiven van de vergelijking met HR 15 januari 1999, ECLI:NL:HR:1999:ZC2820, NJ 2000/49 (Wilderink q.q./Ontvanger) als niet overtuigend, te kort door de bocht. ${ }^{23}$ Weliswaar betrof dat arrest een situatie waarin niet een contractuele uitbreiding van de verrekeningsbevoegdheid ten toets stond, maar de omvang van de wettelijke verrekeningsbevoegdheid van de Ontvanger - in zoverre heeft de A-G volstrekt gelijk -, maar dat doet er niet aan af dat de Hoge Raad het wederkerigheidsvereiste in dit verband 'essentieel' noemt. Waarom dit vereiste dan bij het toetsen van een contractuele uitbreiding van de verrekeningsbevoegdheid opeens niet meer essentieel zou zijn, vermag ik niet in te zien. Een beding op grond waarvan een partij A bevoegd is haar schuld aan partij B te verrekenen met een vordering die zij op een andere partij heeft, met een vordering van een andere partij op partij $B$ of met een vordering van een andere partij op een ander dan de partij B is geen verrekening maar een meerpartijenafspraak, die toevallig dezelfde gevolgen heeft als verrekening.

Het bovenstaande betekent niet dat ik gekant ben tegen een insolventiebestendige contractuele uitbreiding van de verrekeningsbevoegdheid. Dergelijke afspraken maken het financiële marktpartijen die zich in het kader van hun kredietverstrekking bedienen van verschillende entiteiten gemakkelijker om verhaal te nemen op de activa van een debiteur. Men denke in dit verband aan situaties waarbij een tot een financiële groep behorende factormaatschappij bedragen die zij aan een cliënt schuldig is, wil kunnen verrekenen met bedragen die een tot dezelfde financiële groep behorende bank van de cliënt te vorderen heeft, situaties die thans worden geregeld via een overwaardearrangement. Hetzelfde speelt in gevallen waarin een bank schulden aan de ene cliënt wil kunnen verrekenen met vorderingen op een andere cliënt. Dit is bijvoorbeeld aan de orde bij multi-entity cash pooling, waarbij de bank creditsaldi van een deelnemende partij wil kunnen verrekenen met debetsaldi van een andere deelnemende partij. De vraag naar de afdwingbaarheid van multilaterale verrekening in faillissement komt ook vaak aan de orde in de derivatenpraktijk en de clearingpraktijk. Dit speelt met name in een internationale context waarin de contractsdocumentatie niet door Nederlands recht wordt beheerst, maar waarbij het Nederlandse faillissementsrecht in beeld komt met het oog op een mogelijke deconfiture van een Nederlandse contractspartij of clearingdeelnemer. Het faciliteren en faillissementsbestendig maken van dit soort bedingen verbeteren de solvabiliteitspositie van

22. A-G Valk, conclusie voor HR 15 november 2019, ECLI:NL:HR: 2019:1789 (Crienen/Bontrup), ECLI:NL:PHR:2019:783, onder 3.10.

23. A-G Valk, conclusie voor HR 15 november 2019, ECLI:NL:HR: 2019:1789 (Crienen/Bontrup), ECLI:NL:PHR:2019:783, onder 3.13 en 3.14 . financiële marktpartijen en maken kredietverlening goedkoper. Al denk ik overigens dat we de consequenties van het arrest niet moeten overschatten. Ik kom daar nog op terug.

Wat ik wel betreur, is dat de argumenten die ter adstructie van de nieuwe, ruime benadering worden gehanteerd vooral doelredeneringen zijn en dat niet echt wordt ingegaan op het wezen van de verrekening en het karakter en doel van de Faillissementswet, de verhouding tussen de zekerheidsfunctie van de verrekening en het paritasbeginsel. Ook de Hoge Raad maakt zich er mijns inziens wel erg gemakkelijk van af.

\section{Het arrest nader beschouwd}

\subsection{Inhoud van de uitspraak}

In het licht van het bovenstaande lijkt het dienstig om eens te kijken wat de Hoge Raad nu precies heeft overwogen. Laat ik beginnen met een korte schets van de casus. Aan de orde is een door Crienen Transport aanwezig geachte en door Bontrup Holding betwiste verrekeningsafspraak tussen Crienen Transport, Bowie Recycling en Bowie Projecten. Op grond van deze verrekeningsafspraak zou Crienen Transport schulden aan Bowie Recycling mogen verrekenen met vorderingen van Crienen \& Zn op Bowie Projecten en omgekeerd. Crienen Transport wordt na de faillietverklaring van Bowie Recycling en Bowie Projecten aangesproken tot betaling door Bontrup Holding als pandhouder van een vordering van Bowie Recycling en brengt op de betaling in mindering een vordering van Crienen \& $\mathrm{Zn}$ op Bowie Projecten. Crienen Transport beroept zich daarvoor op de pretense verrekeningsafspraak. In cassatie is uitsluitend aan de orde of een meerpartijenverrekeningsafspraak faillissementsbestendig is of niet. Daarbij wordt geabstraheerd van het wel of niet bestaan van de door Crienen Transport gepretendeerde verrekeningsafspraak. In die zin is er sprake van een hypothetische feitelijke grondslag. Het gerechtshof 's-Hertogenbosch, het cassatiemiddel en de Hoge Raad besteden ook geen aandacht aan de omstandigheid dat de wederpartij van Crienen Transport niet de curator van de failliet is, maar Bontrup Holding als pandhouder.

De Hoge Raad beantwoordt de vraag of een meerpartijenverrekeningsafspraak faillissementsbestendig is, bevestigend, dit in navolging van de A-G. De Hoge Raad overweegt:

'3.2 (...) Buiten faillissement kunnen partijen de in art. 6:127 BW geregelde verrekeningsbevoegdheid rechtsgeldig uitbreiden door overeen te komen dat verrekening kan plaatsvinden ook indien zij niet over en weer elkaars schuldeiser en schuldenaar zijn. Er bestaat geen grond om aan een dergelijke overeenkomst haar werking te ontnemen indien een van hen later in staat van faillissement wordt verklaard. Zodanige overeenkomst past bij de zekerheidsfunctie van verrekening en strookt daarom met het zojuist vermelde doel van art. 53 Fw. Het wederkerigheidsvereiste in art. $53 \mathrm{Fw}$ kan daarom niet worden aangemerkt als dwingend recht. 
Art. $53 \mathrm{Fw}$ staat dan ook niet eraan in de weg dat de wederpartij van de partij die in staat van faillissement is verklaard, een beroep doet op een voor de datum van de faillietverklaring tussen hen overeengekomen beding waarbij de bevoegdheid tot verrekening van vorderingen en schulden die voor de datum van de faillietverklaring zijn ontstaan of die voortvloeien uit rechtsverhoudingen die op die datum reeds bestonden, ten behoeve van die wederpartij contractueel is uitgebreid. Die contractuele uitbreiding kan inhouden dat de wederpartij bevoegd is haar schuld te verrekenen met een vordering die een andere partij heeft op een ander dan de failliet.

Het hiervoor in (...) genoemde arrest van de Hoge Raad van 15 januari 1999 betreft een geval waarin een beroep op verrekening plaatsvond zonder dat de bevoegdheid daartoe berustte op de wet of een overeenkomst en is dus niet van toepassing op het onderhavige geval.

3.3 Opmerking verdient dat niet kan worden afgeweken van de regel dat alleen verrekening mogelijk is indien schuld en vordering voor de faillietverklaring zijn ontstaan of voortvloeien uit handelingen die voor de faillietverklaring met de gefailleerde zijn verricht (art. 53 lid 1 Fw). Die regel vloeit voort uit het fixatiebeginsel.'

\subsection{Interpretatie en analyse van overweging 3.2}

Uit overweging 3.2 blijkt expliciet dat de Hoge Raad van oordeel is dat het wederkerigheidsvereiste van art. $53 \mathrm{Fw}$, net als dat van art. 6:127 BW, niet van dwingend recht is en dat art. $53 \mathrm{Fw}$ er dan ook niet aan in de weg staat dat de wederpartij van de gefailleerde jegens de curator een beroep doet op een voor de datum van de faillietverklaring met de gefailleerde overeengekomen beding op grond waarvan zij bevoegd is haar schuld aan de gefailleerde te verrekenen met een vordering van een andere partij op een ander dan de gefailleerde. De Hoge Raad noemt verrekening met een vordering van een andere partij op een ander dan de gefailleerde als een voorbeeld van een mogelijke contractuele uitbreiding van de verrekeningsbevoegdheid. Uit het arrest volgt dat een dergelijke verrekeningsafspraak ook kan inhouden dat de wederpartij van de gefailleerde haar schuld aan de gefailleerde kan verrekenen met een vordering die zij op een andere partij heeft of met een vordering van een andere partij op de gefailleerde. Gelet op de analogie tussen het gelijksoortigheidsvereiste en het wederkerigheidsvereiste ligt het in de rede om aan te nemen dat ook het gelijksoortigheidsvereiste in faillissement of surseance niet van dwingend recht is en dat verrekeningsafspraken waarbij van het gelijksoortigheidsvereiste wordt afgeweken aan de faillissementscurator of de bewindvoerder kunnen worden tegengeworpen.

Zoals ik in paragraaf 5 al aangaf, is het insolventiebestendig zijn van verrekeningsafspraken waarbij wordt afgeweken van het wederkerigheidsvereiste en het gelijksoortigheidsvereiste goed voor financiële marktpartijen. Het zijn dit soort partijen die van dergelijke bedingen gebruik maken in hun algemene voorwaarden en financiële (raam)overeenkomsten. Om te bewerkstelligen dat in een situatie van insolventie aan het wederkerigheidvereiste is voldaan, bedienen zij zich van allerlei constructies. Te noemen zijn in dit verband het bedingen van hoofdelijkheid aan de zijde van de schuldenaren en/of de schuldeisers of het doen stellen van garanties of borgtochten. Met het arrest van de Hoge Raad lijken deze constructies niet langer nodig. Als deze partijen kunnen aantonen dat zij in een insolventiesituatie effectief kruislings kunnen verrekenen - bijvoorbeeld door het overleggen van een legal opinion aan de toezichthouder waarin dit wordt bevestigd -, kan dat bovendien van invloed zijn op de voor hen geldende solvabiliteitseisen voor het kredietrisico. Als zij op een nettobasis solvabiliteit mogen aanhouden, betekent dit dat zij meer ruimte hebben voor kredietverlening en dat zij deze goedkoper kunnen aanbieden. Kortom, vanuit praktisch perspectief een alleszins aanvaardbare beslissing.

Vanuit rechtssystematisch oogpunt daarentegen acht ik de beslissing van de Hoge Raad wel heel erg kort door de bocht. De Hoge Raad volgt integraal de conclusie van de A-G en neemt ook diens onderbouwing over. Dat betekent dat de zekerheidsfunctie van de verrekening op geen enkel moment wordt afgewogen tegen het paritasbeginsel. In feite maakt de Hoge Raad hier gewoon een rechtspolitieke keuze ten faveure van die zekerheidsfunctie zonder zich te bekreunen om de gevolgen die dat voor andere partijen kan hebben. Verder gaat de Hoge Raad, net als A-G Valk, wel erg losjes om met het dwingendrechtelijke karakter van art. 53 Fw. De regel dat de verrekening moet geschieden door degene die zowel schuldenaar als schuldeiser van de gefailleerde is, is volgens de Hoge Raad niet van dwingend recht omdat dit niet zou stroken met het doel van art. $53 \mathrm{Fw}$ dat een schuldeiser van de gefailleerde die tevens schuldenaar van de gefailleerde is, zeker kan zijn van voldoening van zijn vordering door zijn schuld in verrekening te brengen. Dit is een tamelijk merkwaardige en inconsistente redenering om het dwingendrechtelijke karakter van het wederkerigheidsvereiste om zeep te helpen. Het gaat er bij een verrekeningsafspraak als de onderhavige immers niet om dat een schuldenaar zijn schuld aan de gefailleerde in verrekening brengt met zijn vordering op de gefailleerde, maar juist met een vordering die hij op een andere partij heeft, met een vordering van een andere partij op de gefailleerde of van een andere partij op een ander dan de gefailleerde. Met een beroep op de paritas zou net zo gemakkelijk het tegendeel hebben kunnen worden aangenomen. Dat de Hoge Raad aan het winkelen is en alleen die producten in zijn winkelmandje legt die hij zelf lekker vindt, blijkt ook wel uit de omstandigheid dat de regel dat alleen verrekening mogelijk is indien schuld en vordering vóór de faillietverklaring zijn ontstaan of voortvloeien uit handelingen die vóór de faillietverklaring met de gefailleerde zijn verricht blijkens overweging 3.3 van het arrest wel van dwingend recht is. Dat HR 15 januari 1999, ECLI:NL:HR:1999:ZC2820, NJ 2000/49 (Wilderink q.q./ Ontvanger) een geval betreft waarin een beroep op verreke- 
ning plaatsvond zonder dat de bevoegdheid daartoe berustte op de wet of een overeenkomst, zoals de Hoge Raad aan het slot van overweging 3.2 opmerkt, is zeker waar. Maar dat dit arrest daarom niet van toepassing zou zijn op het onderhavige geval en het wederkerigheidsvereiste opeens niet meer essentieel zou zijn, lijkt mij toch echt een drogreden.

\subsection{Interpretatie en analyse van overweging 3.3}

Overweging 3.3 heeft iets van een obiter dictum. De Hoge Raad wijst er nog eens op dat niet kan worden afgeweken van de regel dat alleen verrekening mogelijk is indien schuld en vordering vóór de faillietverklaring zijn ontstaan of voortvloeien uit handelingen die vóór de faillietverklaring met de gefailleerde zijn verricht, omdat deze regel voortvloeit uit het fixatiebeginsel. Dit is in lijn met hetgeen de Hoge Raad in HR 23 maart 2018, ECLI:NL:HR:2018:424 (Credit Suisse/Jongepier q.q.) heeft overwogen over de verificatie van vorderingen in relatie tot het fixatiebeginsel. Volgens de Hoge Raad komen vorderingen die zijn ontstaan tijdens een faillissement in beginsel niet voor erkenning in aanmerking, omdat die erkenning in strijd zou zijn met het fixatiebeginsel. Vorderingen die tijdens het faillissement zijn ontstaan, moeten echter wel worden erkend indien en voor zover zij besloten liggen in een ten tijde van het ingaan van het faillissement reeds bestaande rechtspositie van de schuldeiser. Als de vordering ontstaat of in omvang toeneemt als gevolg van handelingen aan de zijde van de schuldeiser behoort verificatie niet tot de mogelijkheden als het ontstaan of deze toename moet worden aangemerkt als een uitbreiding van de aanspraken zoals die ten tijde van het ingaan van het faillissement al bestonden of in de rechtspositie van deze schuldeiser besloten lagen. Dit laatste - besloten liggen in een ten tijde van het ingaan van het faillissement reeds bestaande rechtspositie van de schuldeiser - lijkt bij uitstek te gelden voor de in art. $53 \mathrm{Fw}$ genoemde tweede categorie van vorderingen, te weten vorderingen die voortvloeien uit handelingen die vóór de faillietverklaring met de gefailleerde zijn verricht. Ik zou voorts menen dat een dergelijke vordering ook voor verificatie in aanmerking komt als zij is ontstaan of in omvang is toegenomen door een handelen van de schuldeiser na de faillietverklaring, waartoe deze op grond van zijn overeenkomst met de gefailleerde bevoegd is. Deze bevoegdheid ligt dan immers al besloten in de rechtspositie van de schuldeiser. Ik denk in dit verband bijvoorbeeld aan de bevoegdheid van een schuldeiser onder een financiële raamovereenkomst tot het aanwijzen van een vervroegde beëindigingsdag waartegen de verplichtingen van partijen worden omgezet in een verplichting tot het betalen van een bedrag dat hun geschatte actuele waarde vertegenwoordigt.

\subsection{Consequenties voor de praktijk}

Als gezegd pleegt de financieringspraktijk zich te bedienen van allerlei constructies om te bewerkstelligen dat in faillissement aan het wederkerigheidsvereiste is voldaan. Te noemen zijn in dit verband het bedingen van hoofdelijkheid aan de zijde van de schuldenaren en/of de schuldeisers of het doen stellen van garanties of borgtochten. Na HR 15 november 2019,
ECLI:NL:HR:2019:1789 (Crienen/Bontrup) lijken deze constructies niet langer nodig om kruislingse verrekening mogelijk te maken in faillissement. Dit speelt bijvoorbeeld bij multi-entity cash pooling (notional pooling). Om zeker te stellen dat de bank zich bij faillissement van een deelnemende groepsmaatschappij met succes op kruislingse verrekening kan beroepen, wordt meestal overeengekomen dat alle deelnemende groepsmaatschappijen jegens de bank hoofdelijk aansprakelijk zijn voor elkaars schulden uit hoofde van een debetsaldo. ${ }^{24}$ Soortgelijke arrangementen vinden we bij multilaterale derivatencontracten en clearingsystemen. Een dergelijke constructie hoeft thans niet meer te worden toegepast om geldig kruislings te kunnen verrekenen.

Het belang van de uitspraak moet echter niet worden overschat. Zo zal het aangaan van een dergelijke meerpartijenverrekeningsafspraak nog altijd doeloverschrijdend, paulianeus of onrechtmatig kunnen zijn en daarmee aantastbaar. Verder zullen banken op grond van de Verordening kapitaalvereisten $(\mathrm{CRR})^{25}$ bij multi-entity cash pooling alleen solvabiliteitsvrijval verkrijgen als zij beschikken over een pandrecht op de creditsaldi. Een multilateraal verrekeningsrecht is daarvoor niet voldoende. ${ }^{26}$ Ten slotte kan het niet zo zijn dat verrekening door een wederpartij van de gefailleerde van haar schuld aan de gefailleerde met een vordering van een andere partij op de gefailleerde of met een vordering van een andere partij op een ander dan de gefailleerde, tussen de verschillende betrokken partijen onderling juridisch zonder gevolgen blijft. Behalve in het geval dat de wederpartij van de gefailleerde haar schuld aan de gefailleerde verrekent met een vordering die deze wederpartij zelf op een andere partij heeft - in welk geval de schuld van de verrekenende partij gedelgd wordt ten laste van haar eigen vermogen -, is er immers steeds sprake van een vermogensverschuiving tussen de verrekenende partij en de derde, wiens vordering (op de gefailleerde of op een andere partij dan de gefailleerde) in verrekening wordt gebracht doordat de schuld van de wederpartij van de gefailleerde aan de gefailleerde wordt gedelgd ten laste van het vermogen van genoemde derde. Denkbaar is dat partijen deze vermogensverschuivingen in stand laten en ze van een titel voorzien door ze in hun boeken te verantwoorden als leningen. Dat zal met name het geval zijn als de betrokken partijen tot een groep van ondernemingen behoren. Het gaat dan om intercompany leningen. Vaak zal het echter de bedoeling van partijen zijn deze onderlinge vermogensverschuivingen ongedaan te maken. Zonder contractuele basis lijkt mij dat niet zo eenvoudig. Wellicht zouden hier regresvorderingen kunnen worden aangenomen op grond van ongerechtvaardigde verrijking. De vraag rijst dan echter of er wel sprake is van een verrijking in die gevallen dat de partij ten laste van wier vermogen de verrekening heeft plaatsgevon-

24. Zie over cash pooling uitvoerig W.A.K. Rank, Van saldocompensatie naar saldoconcentratie?, MvV 2018, afl. 11, p. 327-341.

25. Verordening (EU) 575/2013 van het Europees Parlement en de Raad van 26 juni 2013 betreffende prudentiële vereisten voor kredietinstellingen en beleggingsondernemingen en tot wijziging van Verordening (EU) 648/2012, PbEU 27 juni 2013, L 176/1-337.

26. Zie Rank 2018, p. 337-339. 
den ook zelf van een schuld is bevrijd, en zo ja, of die verrijking wel ongerechtvaardigd is nu zij is terug te voeren op de gemaakte meerpartijenverrekeningsafspraak. De thans in de praktijk gehanteerde hoofdelijkheids- en borgtochtconstructies bieden een kant-en-klaar kader voor het ontstaan en de afwikkeling van regresvorderingen. Zonder dergelijke constructies zullen partijen daar op een andere manier in moeten voorzien. Dat zal in de praktijk zeker een rol spelen bij de vraag of met een enkele multilaterale verrekeningsafspraak kan worden volstaan of dat het toch zin heeft om een hoofdelijkheids- of borgtochtconstructie op te tuigen. ${ }^{27}$

\section{Samenvatting en conclusie}

Uit HR 15 november 2019, ECLI:NL:HR:2019:1789 (Crienen/Bontrup) blijkt dat de Hoge Raad van oordeel is dat het wederkerigheidsvereiste van art. $53 \mathrm{Fw}$, net als dat van art. 6:127 BW, niet van dwingend recht is en dat art. $53 \mathrm{Fw}$ er dan ook niet aan in de weg staat dat de wederpartij van de gefailleerde jegens de curator een beroep doet op een voor de datum van de faillietverklaring met de gefailleerde overeengekomen beding op grond waarvan zij bevoegd is haar schuld aan de gefailleerde te verrekenen met een vordering die zij op een andere partij heeft, met een vordering van een andere partij op de gefailleerde of met een vordering van een andere partij op een ander dan de gefailleerde. Gelet op de analogie tussen het gelijksoortigheidsvereiste en het wederkerigheidsvereiste ligt het in de rede om aan te nemen dat ook het gelijksoortigheidsvereiste in faillissement of surseance niet van dwingend recht is en dat verrekeningsafspraken waarbij van het gelijksoortigheidsvereiste wordt afgeweken aan de faillissementscurator of de bewindvoerder kunnen worden tegengeworpen. Afwijking van de regel dat alleen verrekening mogelijk is indien schuld en vordering vóór de faillietverklaring zijn ontstaan of voortvloeien uit handelingen die vóór de faillietverklaring met de gefailleerde zijn verricht, is volgens het arrest niet toegestaan, omdat deze regel voortvloeit uit het fixatiebeginsel.

Vanuit praktisch perspectief betreft het hier een alleszins aanvaardbare beslissing. Financiële marktpartijen behoeven zich in meerpartijenverhoudingen niet meer van allerlei constructies te bedienen om wederkerigheid te creëren teneinde in een insolventiesituatie kruislings te kunnen verrekenen. Het faciliteren en faillissementsbestendig maken van dit soort bedingen verbetert de solvabiliteitspositie van financiële marktpartijen en maakt kredietverlening goedkoper. Tegelijk past hierbij de kanttekening dat de consequenties van het arrest niet moeten

27. In theorie zou kunnen worden betoogd dat in die gevallen dat de failliete boedel door de multilaterale verrekening een vordering op een debiteur verliest zonder dat daar een eigen schuldplichtigheid van de boedel tegenover stond, sprake is van verrijking van de desbetreffende debiteur ten koste van de boedel, en dat de curator in die gevallen een vordering uit ongerechtvaardigde verrijking jegens de desbetreffende debiteur zou moeten kunnen instellen. Voor een dergelijke actie is mijns inziens geen grond. De verrijking, zo daarvan al sprake is, is immers niet ongerechtvaardigd, omdat zij haar grondslag vindt in de gemaakte verrekeningsafspraak. Het aannemen van een vordering uit ongerechtvaardigde verrijking staat haaks op de strekking van deze afspraak en zou haar zinledig maken. worden overschat. Er zal immers behoefte blijven aan het redresseren van een als gevolg van multilaterale verrekening opgetreden vermogensverschuiving tussen de verrekenende partij en de derde ten laste van wiens vermogen de schuld is gedelgd. Beperken partijen hun contractuele regeling tot een enkele multilaterale verrekeningsafspraak met de latere gefailleerde, dan lijken onderlinge regresvorderingen alleen op ongerechtvaardigde verrijking te kunnen worden gebaseerd. De bestaande hoofdelijkheids- en borgtochtconstructies daarentegen bieden partijen een panklare regeling voor het ontstaan en de afwikkeling van de benodigde regresvorderingen. Vanuit rechtssystematisch oogpunt is er op de beslissing het nodige aan te merken. De Hoge Raad volgt integraal de conclusie van de A-G en neemt ook diens onderbouwing over. Dat betekent dat de zekerheidsfunctie van de verrekening op geen enkel moment wordt afgewogen tegen het paritasbeginsel. Verder komt de Hoge Raad op basis van een aanvechtbare redenering tot het oordeel dat de regel van art. $53 \mathrm{Fw}$ dat de verrekening moet geschieden door degene die zowel schuldenaar als schuldeiser van de gefailleerde is, niet van dwingend recht is en neemt hij wel erg gemakkelijk afstand van zijn eerder in ander verband gedane uitspraak waarin het wederkerigheidsvereiste van art. $53 \mathrm{Fw}$ een essentieel vereiste voor verrekening werd genoemd. 